DE

M E D I C I N A

T R O P I C A L

$\mathrm{DE}$

SÃO PAULO

JOURNAL OF THE SÃO PAULO INSTITUTE OF TROPICAL MEDICINE

'Universidade de São Paulo, Faculdade de Medicina de Ribeirão Preto, Programa de Pós-Graduação Strictu Sensu em Saúde na Comunidade, Ribeirão Preto, São Paulo, Brazil

2Universidade Federal do Triângulo Mineiro, Departamento de Saúde Coletiva, Programa de Pós-Graduação Strictu Sensu em Atenção à Saúde, Uberaba, Minas Gerais, Brazil

${ }^{3}$ Universidade Federal do Triângulo Mineiro, Departamento de Saúde Coletiva, Programa de Pós-Graduação Strictu Sensu em Inovação Tecnológica, Uberaba, Minas Gerais, Brazil

${ }^{4}$ Universidade de Uberaba, Faculdade de Odontologia, Uberaba, Minas Gerais, Brazil

${ }^{5}$ Faculdade Alfredo Nasser, Faculdade de Medicina, Aparecida de Goiânia, Goiás, Brazil

Correspondence to: Sybelle de Souza Castro

Universidade Federal do Triângulo

Mineiro, Departamento de Saúde Coletiva, Programa de Pós-Graduação Strictu Sensu em Atenção à Saúde, Rua Vigário Carlos $n^{\circ}$ 100, Abadia, CEP 38025-350, Uberaba, MG, Brazil

Tel: +55 34 3700-6924,

Mobile: +55 34 99978-3315

E-mail: sybelle.castro@uftm.edu.br

Received: 20 September 2018

Accepted: 14 February 2019

\section{Characteristics of cases of tuberculosis coinfected with HIV in Minas Gerais State in 2016}

\author{
Sybelle de Souza Castro ${ }^{1,2}$, Lúcia Marina Scatena ${ }^{3}$, Alfredo Miranzi ${ }^{4}$, Almir \\ Miranzi Neto ${ }^{5}$, Altacílio Aparecido Nunes ${ }^{1}$
}

\section{ABSTRACT}

This study aimed to characterize the cases of tuberculosis (TB) co-infected with the human immunodeficiency virus (HIV) in Minas Gerais State, Brazil, after the notification sheet modification, and to verify the association between the new variables and the treatment outcome. It is an analytical cross-sectional study with TB/HIV cases notified in the year 2016 to the Brazilian Information System for Notifiable Diseases (Sistema de Informação de Agravos de Notificação). Descriptive statistics, chi-square test, and multiple correspondence analysis were performed to verify the association between the outcome, ageand associated diseases. Of the 180 cases, most were male (75.6\%) between 30 and 49 years old $(63.3 \%)$, mixed ethnicity (black and white) $(49.4 \%), 94.4 \%$ had the Acquired Immunodeficiency Syndrome (AIDS) and $60.6 \%$ had pulmonary TB. The molecular test was not performed at the time of diagnosis in $70.5 \%$ of the cases. Homeless people $(4.4 \%)$ and prisoners $(3.9 \%)$ featured prominently among the special populations. People between 40 and 49 years old without concurrent diseases were cured in $40.0 \%$ of the cases; $18.9 \%$ abandoned the treatment due to smoking, drug abuse and mental illness in the age group between 20 and 29 years old. The deaths were associated with the age group between 30 and 39 years old and the occurrence of AIDS. The results have shown that the groups considered vulnerable (drug users, smokers and people with mental illness) abandoned the treatment, the notification upon death from AIDS in adults was late and some treatments were inadequate. The epidemiological surveillance, prevention and assistance strategies towards cases of TB/HIV must be improved in order to achieve the goal of the Brazilian National Plan to end Tuberculosis as a Public Health Problem until 2035 in the state.

KEYWORDS: HIV. Acquired Immunodeficiency Syndrome. Tuberculosis. Factor analysis.

\section{INTRODUCTION}

Tuberculosis (TB) is the $9^{\text {th }}$ cause of death around the world. In 2016, 1.3 million deaths from TB were estimated among HIV-negative people and 374,000 deaths were estimated among HIV-positive people. Of the total cases of TB/HIV, $85 \%$ were on antiretroviral therapy (ART), and the successful rate of treatment was $78 \%{ }^{1}$. The specific goals to eradicate TB until 2030 include $90 \%$ reduction in deaths and $80 \%$ reduction of TB incidence per year ${ }^{1}$. One of the factors hindering the elimination of TB is the emergence of HIV/Aids epidemics, since HIV-positive individuals are more likely to have the disease throughout their lives ${ }^{2-4}$.

HIV has a huge impact on perpetuation of TB, increasing the incidence and mortality rates of the disease ${ }^{5}$. Other conditions and diseases that also interfere with the immunological state enabling the emergence of latent TB, such as alcohol 
consumption, illicit drugs, smoking and the presence of chronic diseases, like diabetes ${ }^{6}$. These chronic factors may interfere with the outcomes of TB/HIV coinfection (cure, deaths, and abandonment of treatment $)^{7}$. It is recommended that every patient with TB should be tested for HIV, but, in many regions, the frequency of notified cases of TB that were positive for HIV is $\operatorname{low}^{1,2,8,9}$.

In Brazil, at the end of 2014, there was a change in TB notification and the compulsory notification became mandatory in the HIV-positive cases. The new notification encompassed the identification of associated factors that may favor the emergence of the disease and cause complications, the identification of populations vulnerable to the infection, the result of the rapid molecular test and the use of ART. Given the introduction of a new TB notification, it was necessary to assess the association of treatment outcomes after the inclusion of these new variables. The purpose of this work is to characterize the cases of TB coinfected with HIV and to verify the combination of the new variables with the closure status of the cases.

\section{MATERIALS AND METHODS}

This was an analytical cross-sectional study with reported cases of TB coinfected with HIV in Minas Gerais State, Brazil, in 2016, registered in the Brazilian Information System for Notifiable Diseases (SINAN), provided by the State Office of Health of Minas Gerais (SES/MG - Secretaria do Estado da Saúde de Minas Gerais). Minas Gerais State has 853 cities with 21,119,536 inhabitants (in 2017), and is considered the second most populated state in Brazil.

Due to the period of implantation and adaptation to the new TB notification in the state, 2016 was the year chosen because it contains cases after this phase and the cases had a concluded closure status with respect to treatment, considering that TB is treated for at least 6 months.

Variables selected for this study were: cases of TB/HIV, closure status (cure, abandonment, death from $\mathrm{TB}$, death from other causes), age group, sex, ethnicity, education, district, pregnant woman, type of entrance, special populations (prisoners, healthcare practitioners, immigrants, homeless people), type of disease (pulmonary, extra-pulmonary or pulmonary and extra-pulmonary), associated diseases and disorders (AIDS, alcoholism, diabetes, smoking, mental illness, illicit drug abuse), sputum smear microscopy, chest X-ray, ART use and HIV test, as well as the rapid molecular test. Blank data or data specified as a not specified category was considered unknown ${ }^{10}$.

The inclusion criteria were new cases notified in 2016 with closure status defined as cured, abandoned, death from
TB and death from other causes. Blank outcomes (without a defined closure status) were excluded.

Data were analyzed with the Statistica software version 10 (StatSoft, USA), through descriptive statistics, and the differences between proportions of the variables and the closure status of the case were verified through the Chi-square test. The variables with significant difference $(\mathrm{p} \leq 0.05)$ were included in the Multiple Correspondence Analysis (MCA), enabling to verify the association between the "additional" variable closure status of the case with the other "active" variables in a factorial plan ${ }^{11-13}$.

The project was approved by the Human Research Ethics Committee of the Federal University of Triangulo Mineiro (UFTM - Universidade Federal do Triângulo Mineiro), opinion $\mathrm{N}^{\circ}$ 2.099.176. The Free and Informed Consent was not used as we dealt with secondary data from a database and had no variables identifying the participants.

\section{RESULTS}

In 2016, 466 cases of TB/HIV coinfection were notified in Minas Gerais State. Of these, 180 met the inclusion criteria. Of the cases analyzed, $75.6 \%$ were male, most of them in the age groups between 30 and 39 years old (36.7\%) and between 40 and 49 years old (25.6\%), were mixed ethnicity (black and white) (49.4\%) or white (27.5\%), living in the urban area $(97.0 \%)$ (Table 1). Cases of pregnant women were not registered in this year and there was a high rate of unknown education (53.9\%); $40.0 \%$ of the cases were cured, $18.9 \%$ abandoned treatment and $33.9 \%$ passed away for causes other than TB.

The predominant clinical form was pulmonary (60.6\%), followed by extra-pulmonary (28.9\%). The predominant diagnostic method was the chest X-ray (73.6\%) of the cases. The rapid molecular test and the sensitivity test had not yet been implemented in Minas Gerais State, and were not performed in $70.5 \%$ and $57.1 \%$ of the cases, respectively (Table 2).

Among the cases, $94.4 \%$ had AIDS with an associated disease, and only $57.4 \%$ were on ART, $30.7 \%$ were alcoholic, $23.5 \%$ used illicit drugs and $26.8 \%$ were smokers (Table 3). Among the special populations, homeless people $(4.5 \%)$, prisoners $(3.9 \%)$ and beneficiaries of government programs $(3.9 \%)$ featured prominently. Cases in healthcare practitioners were not registered.

The multiple correspondence analysis considered the new cases of TB coinfected with HIV/AIDS where the outcome variable was the closure status regarding the cure, abandonment and deaths from TB and other causes. It was verified that the deaths from TB were associated with the age group between 50 and 59 years old, whereas the deaths 
Table 1 - Distribution of the sociodemographic profile of TB/HIV coinfection cases, Minas Gerais State, Brazil, 2016.

\begin{tabular}{|c|c|c|c|c|c|c|}
\hline Variables & $\begin{array}{l}\text { Healing } \\
\text { N (\%) }\end{array}$ & $\begin{array}{c}\text { Abandonment } \\
\mathrm{N}(\%)\end{array}$ & $\begin{array}{c}\text { Death TB } \\
\text { N (\%) }\end{array}$ & $\begin{array}{c}\text { Death other } \\
\text { causes } \\
\mathrm{N}(\%)\end{array}$ & $\begin{array}{l}\text { Total } \\
\text { N (\%) }\end{array}$ & $\mathrm{p}$ \\
\hline Gender & & & & & & 0.35 \\
\hline Male & $57(31.7)$ & $22(12.2)$ & $11(6.1)$ & $46(25.6)$ & $136(75.6)$ & \\
\hline Female & $15(8.3)$ & $12(6.7)$ & $2(1.1)$ & $15(8.3)$ & $44(24.4)$ & \\
\hline Age group & & & & & & 0.01 \\
\hline 0 to 9 years old & $1(0.6)$ & $1(0.6)$ & $0(0.0)$ & $1(0.6)$ & $3(1.7)$ & \\
\hline From 10 to 19 years old & $1(0.6)$ & $0(0.0)$ & $0(0.0)$ & $0(0.0)$ & $1(0.6)$ & \\
\hline From 20 to 29 years old & $11(6.1)$ & $6(3.3)$ & $0(0.0)$ & $11(6.4)$ & $28(15.6)$ & \\
\hline From 30 to 39 years old & $21(11.0)$ & 19(10.6) & $5(2.8)$ & $21(11,7)$ & $66(36.7)$ & \\
\hline From 40 to 49 years old & $23(12.8)$ & $7(3.9)$ & $2(1.1)$ & $14(7.8)$ & $46(25.6)$ & \\
\hline From 50 to 59 years old & $13(7.2)$ & $1(0.6)$ & $2(1.1)$ & $11(6.1)$ & $27(15.0)$ & \\
\hline$\geq 60$ years old & $2(1.1)$ & $0(0.0)$ & $4(2.2)$ & $3(1.7)$ & $9(5.0)$ & \\
\hline Education & & & & & & 0.11 \\
\hline $1^{\text {st }}$ to $4^{\text {th }}$ grades ${ }^{\mathrm{a}} \mathrm{C}$ and I & $11(6.1)$ & $4(2.2)$ & $3(1.7)$ & $8(4.4)$ & $26(14.4)$ & \\
\hline $5^{\text {th }}$ to $8^{\text {th }}$ grades ${ }^{\mathrm{a}} \mathrm{C}$ and I & $18(10.0)$ & $4(2.2)$ & $4(2.2)$ & $8(4.4)$ & $34(18.9)$ & \\
\hline High school ${ }^{\mathrm{a}} \mathrm{C}$ and I & $5(2.8)$ & $7(3.9)$ & $0(0.0)$ & $1(0.6)$ & $13(7.2)$ & \\
\hline Higher education ${ }^{\mathrm{a}} \mathrm{C}$ and I & $4(2.2)$ & $0(0.0)$ & $0(0.0)$ & $2(1.1)$ & $6(3.3)$ & \\
\hline Illiterate & $1(0.6)$ & $0(0.0)$ & $0(0.0)$ & $0(0.0)$ & $1(0.6)$ & \\
\hline Not applicable & $1(0.6)$ & $1(0.6)$ & $0(0.0)$ & $1(0.6)$ & $3(1.7)$ & \\
\hline Ignored & $32(17.8)$ & $18(10.0)$ & $6(3.3)$ & $41(22.8)$ & $97(53.9)$ & \\
\hline Ethnicity & & & & & & 0.73 \\
\hline Mixed (Black and White) & $32(18.0)$ & $22(12.4)$ & $6(3.4)$ & $28(15.80)$ & $88(49.4)$ & \\
\hline White & $22(12.4)$ & $6(3.4)$ & $3(1.7)$ & $18(10.1)$ & $49(27.5)$ & \\
\hline Black & $12(6.7)$ & $4(2.3)$ & $4(2.3)$ & $9(5.0)$ & $29(16.3)$ & \\
\hline Ignored & $6(2.3)$ & $2(1.1)$ & $0(0.0)$ & $5(2.8)$ & $13(6.2)$ & \\
\hline Asian & $1(0.6)$ & $0(0.0)$ & $0(0.0)$ & $0(0.0)$ & $1(0.6)$ & \\
\hline Zone & & & & & & 0.65 \\
\hline Urban & $68(39.5)$ & $28(16.3)$ & $11(6.4)$ & $60(34.9)$ & $167(97.0)$ & \\
\hline Rural & $2(1.2)$ & $1(0.6)$ & $1(0.6)$ & $1(0.6)$ & $5(2.9)$ & \\
\hline
\end{tabular}

${ }^{\mathrm{a}} \mathrm{C}$ and $\mathrm{I}=$ complete and incomplete. Data source: Notification of Injury Information System from the Minas Gerais State.

from other causes were mainly associated with AIDS, lack of information regarding other associated diseases and age between 30 and 39 years old. People cured were associated with absence of diseases and were in the age group between 40 and 49 years old, meanwhile, the cases of abandonment of treatment were associated with the age group between 20 and 29 years old and with illicit drug use, smoking, and mental illness, as well as diseases associated with TB/HIV coinfection. HIV infection without AIDS was associated with patients under the age of 19 years old (Figure 1).

\section{DISCUSSION}

Many factors increase the susceptibility to infection by
Mycobacterium tuberculosis, such as impairment of the immune system by several diseases and medicines, like HIV and AIDS, type II diabetes, terminal kidney disease, alcoholism, intravenous drug abuse, certain types of cancer, chemotherapy to treat cancer, malnutrition and very young or advanced age. Some other factors include the use of tobacco, which increases the risk of contracting and dying due to $\mathrm{TB}^{14,15}$.

The insertion of the variable "diseases and disorders associated" to TB, included in the notification, was correlated with the treatment outcomes, being a favorable indication of its importance to assess and supervise the cases of TB/HIV. The insertion of the variable "special populations" showed low number of cases in which 
Table 2 - Distribution of TB/HIV coinfection cases, according to the results of molecular tests and the sensitivity test, smear microscopy after 6 months of treatment, chest X-Ray and clinical form, Minas Gerais State, Brazil, 2016.

\begin{tabular}{|c|c|c|c|c|c|c|}
\hline Variables & $\begin{array}{l}\text { Cure } \\
\mathrm{N}(\%)\end{array}$ & $\begin{array}{c}\text { Abandonment } \\
\mathrm{N}(\%)\end{array}$ & $\begin{array}{l}\text { Death TB } \\
N(\%)\end{array}$ & $\begin{array}{l}\text { Death other } \\
\text { causes } \\
N(\%)\end{array}$ & $\begin{array}{l}\text { Total } \\
\mathrm{N}(\%)\end{array}$ & $\mathrm{p}$ \\
\hline Rapid Molecular test for TB & & & & & & 0.09 \\
\hline Not performed & $48(27.3)$ & $21(12.0)$ & $9(5.1)$ & $46(26.1)$ & $124(70.45)$ & \\
\hline Detectable sensitive to rifampicin & $13(7.4)$ & $6(3.4)$ & $1(0.6)$ & $6(3.4)$ & $26(14.8)$ & \\
\hline Not detectable & $8(4.6)$ & $6(3.4)$ & $0(0.0)$ & $6(3.4)$ & $20(11.3)$ & \\
\hline Detectable rifampicin resistant & $1(0.6)$ & $0(0.0)$ & $0(0.0)$ & $0(0.0)$ & $1(0.6)$ & \\
\hline Inconclusive & $0(0.0)$ & $0(0.0)$ & $2(1.1)$ & $3(1.7)$ & $5(2.8)$ & \\
\hline Sensitivity Test ${ }^{a}$ & & & & & & 0.55 \\
\hline Not performed & $8(22.9)$ & $5(14.3)$ & $1(2.9)$ & $6(17.2)$ & $20(57.1)$ & \\
\hline In progress & $1(2.9)$ & $0(0.0)$ & $0(0.0)$ & $0(0.0)$ & $1(2.9)$ & \\
\hline Sensitive & 8 (22.9) & $0(0.0)$ & $0(0.0)$ & $2(5.7)$ & $10(28.6)$ & \\
\hline Resistant to other first line drugs & $0(0.0)$ & $1(2.9)$ & $0(0.0)$ & $0(0.0)$ & $1(2.9)$ & \\
\hline Resistant to isoniazid & $1(2.9)$ & $1(2.9)$ & $0(0.0)$ & $1(2.9)$ & $3(8.6)$ & \\
\hline Smear microscopy after 6 months & & & & & & 0.47 \\
\hline Not applicable & $27(35.6)$ & $10(13.2)$ & $2(2.6)$ & $20(26.3)$ & $59(77.6)$ & \\
\hline Not performed & $5(6.6)$ & $1(1.3)$ & $1(1.3)$ & $3(4.0)$ & $10(13.2)$ & \\
\hline Negative & $6(7.9)$ & $0(0.0)$ & $0(0.0)$ & $0(0.0)$ & $6(7.9)$ & \\
\hline Positive & $1(1.3)$ & $0(0.0)$ & $0(0.0)$ & $0(0.0)$ & $1(1.3)$ & \\
\hline Chest X-Ray & & & & & & 0.21 \\
\hline Suspect & $52(29.2)$ & $28(15.7)$ & $9(5.0)$ & $42(23,6)$ & $131(73.6)$ & \\
\hline Normal & $11(6.2)$ & $4(2.2)$ & $0(0.0)$ & $10(5.6)$ & $25(14.0)$ & \\
\hline Not performed & $6(3.4)$ & $2(1.1)$ & $4(2.2)$ & $5(2.8)$ & $17(9.5)$ & \\
\hline Other pathology & $2(1.1)$ & $0(0.0)$ & $0(0.0)$ & $3(1.7)$ & $5(2.8)$ & \\
\hline Clinical form & & & & & & 0.32 \\
\hline Pulmonary & $37(20.6)$ & $24(13.3)$ & $10(5.6)$ & $38(21.1)$ & $109(60.6)$ & \\
\hline Extra-pulmonary & $24(13.3)$ & 7 (93.9) & $2(1.1)$ & 19 (10.6) & $52(28.9)$ & \\
\hline Pulmonary and extra-pulmonary & $11(6.1)$ & $3(1.7)$ & $1(0.6)$ & $4(2.2)$ & $19(10.6)$ & \\
\hline
\end{tabular}

anly 35 responded. Data source: Notification of Injury Information System from the Minas Gerais State.

information was provided and they were not associated with the outcome in the $\mathrm{MCA}^{12,13}$.

An association between treatment abandonment and diseases associated with smoking, illicit drug use and mental illness was observed. The ratio of people abandoning the treatment was $18.9 \%$, higher than the ratio verified in Alagoas State $(10.42 \%)$ and Piaui State $(4.8 \%)^{2}$.

Tobacco smoking interferes by suppressing the activation of the immune response inherent to bacterial infections. Nicotine may inhibit the signaling of T cells and production of antibodies, in addition to a potential inhibition of apoptosis, a defense mechanism against TB infection ${ }^{15,16}$. Studies indicate that alcohol and drug consumption favor abandonment of treatment, as well as poverty and low education ${ }^{7}$. The improper alcohol consumption also impairs the immune system, inhibiting cellular functioning and hindering the destruction of invasive microorganisms. It also interferes with the production of signaling molecules that directly help the immune response, such as cytokines, increasing the susceptibility to $\mathrm{TB}^{15}$. In a literature review study, Cruz et al. ${ }^{17}$ reported that the illicit drug abuse favors the dissemination of TB. Crack (cocaine) induces cough, favors intimate contact in closed environments and intermittent people flow. In addition, there was spread of HIV infection among malnourished drug users as malnutrition makes the users even more vulnerable. 
Table 3 - Distribution of TB/HIV coinfection cases, according to types of associated aggravations and use of antiretroviral therapy, Minas Gerais State, Brazil, 2016.

\begin{tabular}{|c|c|c|c|c|c|c|}
\hline Associated aggravations & $\begin{array}{l}\text { Cure } \\
\mathrm{N}(\%)\end{array}$ & $\begin{array}{c}\text { Abandonment } \\
\mathrm{N}(\%)\end{array}$ & $\begin{array}{l}\text { Death TB } \\
\mathrm{N}(\%)\end{array}$ & $\begin{array}{c}\text { Death other causes } \\
N(\%)\end{array}$ & $\begin{array}{l}\text { Total } \\
\mathrm{N}(\%)\end{array}$ & $p$ \\
\hline Aids & & & & & & 0.01 \\
\hline Yes & $67(37.2)$ & $32(17.8)$ & $10(5.6)$ & $61(33.9)$ & $170(94.4)$ & \\
\hline No & $5(2.8)$ & $1(0.6)$ & $3(1.7)$ & $0(0.0)$ & $9(5.0)$ & \\
\hline Ignored & $0(0.0)$ & $1(0.6)$ & $0(0.0)$ & $0(0.0)$ & $1(0.6)$ & \\
\hline Alcohol & & & & & & 0.15 \\
\hline Yes & $17(9.5)$ & $12(6.7)$ & $5(2.8)$ & $21(11.7)$ & $55(30.7)$ & \\
\hline No & 49 (27.3) & $19(10.6)$ & $6(3.5)$ & $27(15.1)$ & $101(56.4)$ & \\
\hline Ignored & $6(3.3)$ & $3(1.7)$ & $2(1.1)$ & $12(6.7)$ & $23(12.8)$ & \\
\hline Diabetes & & & & & & 0.07 \\
\hline Yes & $1(0.6)$ & $1(0.6)$ & $0(0.0)$ & $1(0.6)$ & $3(1.7)$ & \\
\hline No & $68(38.0)$ & $31(17.3)$ & $9(5.0)$ & $54(30.2)$ & $162(90.5)$ & \\
\hline Ignored & $3(1.7)$ & $2(1.1)$ & $4(2.2)$ & $5(2.8)$ & $14(7.8)$ & \\
\hline Mental illness & & & & & & 0.04 \\
\hline Yes & $0(0.0)$ & $2(1.1)$ & $0(0.0)$ & $1(0.6)$ & $3(1.7)$ & \\
\hline No & $70(39.1)$ & $30(16.8)$ & $10(5.6)$ & $55(30.8)$ & $165(92.2)$ & \\
\hline Ignored & $2(1.1)$ & $2(1.1)$ & $3(1.7)$ & $5(2.4)$ & $12(6.1)$ & \\
\hline Other & & & & & & 0.46 \\
\hline Yes & $3(2.0)$ & $1(0.7)$ & $2(1.3)$ & $5(3.3)$ & $11(7.3)$ & \\
\hline No & 49 (32.7) & $23(15.3)$ & $7(4.7)$ & $42(28.0)$ & $121(80.7)$ & \\
\hline Ignored & $7(4.7)$ & $2(1.3)$ & $3(2.0)$ & $6(4.0)$ & $18(12.0)$ & \\
\hline Use of illicit drugs & & & & & & 0.00 \\
\hline Yes & $9(5.0)$ & $18(10.1)$ & $1(0.6)$ & $14(7.8)$ & $42(23.5)$ & \\
\hline No & $53(29.6)$ & $11(6.1)$ & $9(5.0)$ & $31(17.3)$ & $104(58.1)$ & \\
\hline Ignored & $10(5.6)$ & $5(2.8)$ & $3(1.7)$ & $15(8.4)$ & $33(18.4)$ & \\
\hline Tobacco smoking & & & & & & 0.00 \\
\hline Yes & $18(10.1)$ & $13(7.3)$ & $3(1.7)$ & $14(7.8)$ & $48(26.8)$ & \\
\hline No & 50 (27.9) & $18(10.1)$ & $4(2.2)$ & $36(20.1)$ & $108(60.3)$ & \\
\hline Ignored & $4(2.2)$ & $3(1.7)$ & $6(3.3)$ & $10(5.6)$ & $23(12.9)$ & \\
\hline Use of antiretroviral therap & & & & & & 0.03 \\
\hline Yes & 38 (27.9) & $13(9.6)$ & $6(4.4)$ & $21(15.4)$ & $78(57.4)$ & \\
\hline No & $9(6.6)$ & $10(7.4)$ & $3(2.2)$ & $21(15.4)$ & $43(31.6)$ & \\
\hline Ignored & $7(5.1)$ & $2(1.5)$ & $3(2.2)$ & $3(2.2)$ & $15(11.0)$ & \\
\hline
\end{tabular}

Data source: Notification of Injury Information System from the Minas Gerais State.

Another literature review study indicates that the illicit drug abuse favors the low adherence to and the abandonment of treatment. The stereotypes associated with drug abuse poses an obstacle in the appropriate approach to users, and the healthcare practitioners do not have a specific ability to make this approach ${ }^{18}$.

Other factors may also contribute to the non-adherence to treatment, such as the use of other medicines, the type of medicine, history of previous treatment of TB and previous abandonment, the lack of training of healthcare practitioners, low doctor-patient interaction, need to hospitalization, operational problems to follow the treatment, fear to be stigmatized and discriminated after the disclosure of the HIV diagnosis, side effects and drugs 


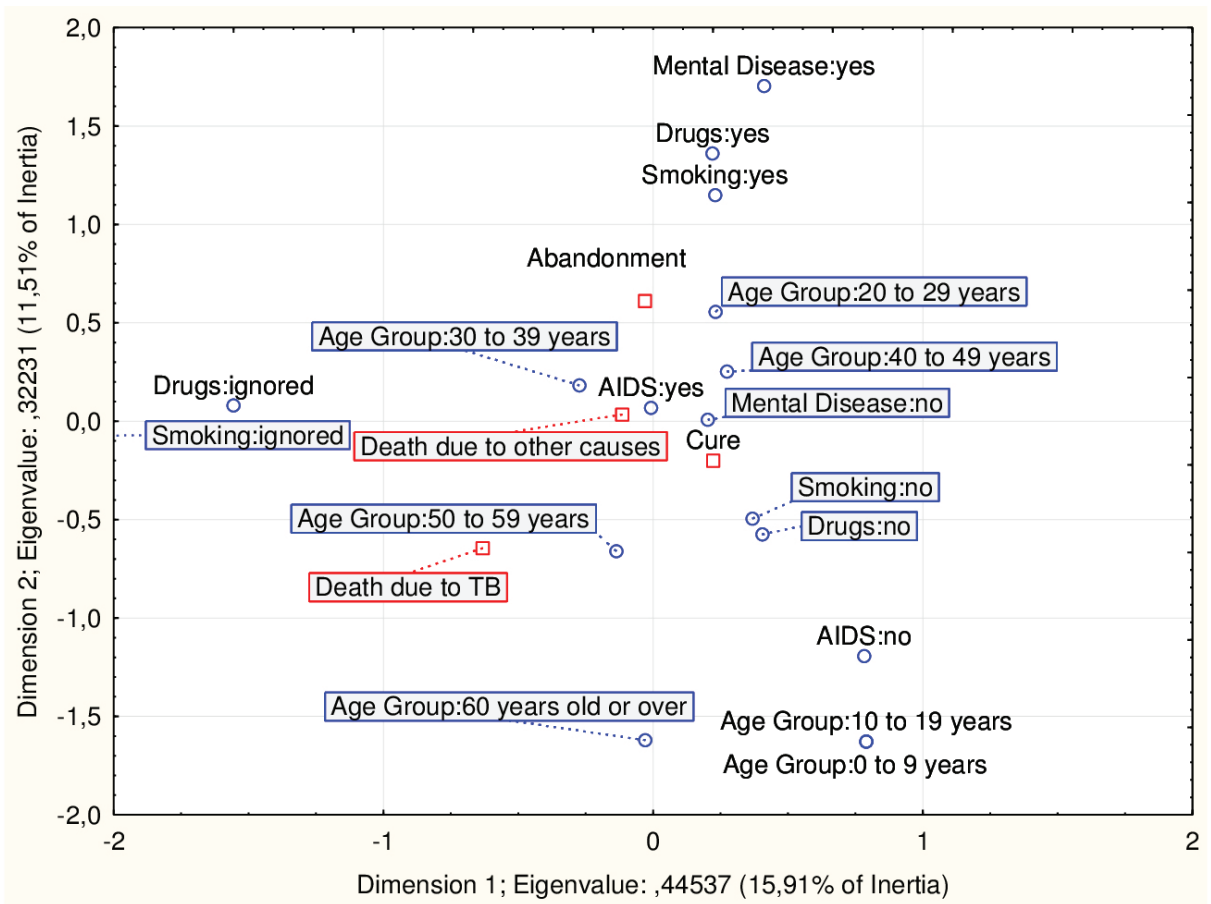

Figure 1 - Factors associated with the closure of the TB/HIV coinfection cases, Minas Gerais State, Brazil, 2016.

toxicity, the patient's disbelief in the treatment efficacy, complexity of treatment, different place to treat TB and HIV/AIDS, difficulty to give the TB diagnosis to patients with AIDS, depression and no social support ${ }^{18}$.

It is known that the pulmonary TB is relevant to the public health due to its high infectivity and the easy diagnosis in comparison to other types of $\mathrm{TB}$, helping to interrupt the chain of transmission ${ }^{2,19}$. Pulmonary TB was predominant $(60.6 \%)$, followed by extrapulmonary TB $(28.9 \%)$. A similar result of $62.7 \%$ was observed in a study carried out in the city of Contagem, Minas Gerais State ${ }^{20}$. In a national-based study, a similar result was also observed, between $37 \%$ and $40 \%$ for extrapulmonary TB, and 59\% and $62 \%$ for pulmonary $\mathrm{TB}^{21}$. The results are also similar to the ones found in Ethiopia, where $51.8 \%$ of the patients had pulmonary $\mathrm{TB}$ and $44 \%$ had extrapulmonary $\mathrm{TB}^{22}$.

In 2014, the Rapid Molecular Test Network (RTR-TB Rede de Teste Rápido Molecular) was implemented in the public health system in order to diagnose TB and there was progress during the first years of RTR-TB use. The test is important to reduce the spread of the disease, since it detects the presence or absence of the bacillus, quickly shows the resistance to rifampicin, facilitating the work process of healthcare teams and the epidemiological surveillance, speeding up the beginning of treatment, whether TB is resistant or not to the drugs ${ }^{23}$. In Minas Gerais State, many individuals were not submitted to the molecular test $(70.45 \%)$ and to the drug-sensitivity test $(57.1 \%)$, being an indication that RTR-TB has not shown epidemiological impacts in Minas Gerais State so far according to the results,probably due to the fact that Minas Gerais was the $15^{\text {th }}$ state to perform the test and one of the states with higher rates of underused equipments ${ }^{23-25}$.

Most cases of TB/HIV were in male adults (75.6\%), with acquired immunodeficiency syndrome (AIDS) and pulmonary TB. Belo et al. ${ }^{26}$ found a significant difference between sex and delay in the diagnosis of the disease, being higher in women than in men $(\mathrm{p}<0.05)$, which can be explained by the differences in behavior between genders, being reported that men had early and rapid access to quality health services. The high proportion of cases in males with working age between 30 and 49 years old $(63.3 \%)$, being most of mixed ethnicity (black and white) (49.4\%), was also observed in other researches using SINAN in different states of Brazil ${ }^{2,21}$. Magno et al. ${ }^{21}$ verified predominance in males (>71\%), in the age group between 25 and 40 years old ( $>53 \%)$, in mixed ethnicity (black and white) patients $(>83 \%)$. A study carried out in Piaui State between 2007 and 2016 with cases of TB/HIV coinfection has also observed predominance in males (75.4\%), in the age group between 20 and 49 years old $(79.5 \%)$ and in mixed ethnicity (black and white) patients $(73.8 \%)^{2}$.

Considering that almost every patient had AIDS and that a little more than half of them used ART (57.4\%), which is important for the the immune system function, the low percentage of cure (40\%) and the significant number of patients abandoning treatment may be related to the low adherence to ART and to diseases and disorders associated 
with TB. All cases were of TB coinfected with HIV and, therefore, they should be on medication recommended to all HIV-positive patients regardless of their $\mathrm{CD} 4$ count and the virus count, according to a 2013 recommendation ${ }^{24}$, and that the treatment of the TB/HIV coinfection follows the same principles that the one in non-HIV infected individuals ${ }^{27}$. ART reduces the risk of TB among people living with HIV/AIDS in $67 \%$ and, if expanded, may contribute to reduce TB rates at the population level ${ }^{28-30}$.

TB/HIV coinfection may favor resistance to drugs, attributed to the immunological state and potential abandonments prior to treatment. The proportion of TB multi-resistant to other first-class drugs was $2.9 \%$, a rate higher than the one verified in a study by Gaspar et at. ${ }^{31}$ who reported it in $0.17 \%$ in patients coinfected with TB/HIV and in a study by Silva et al..$^{32}$ in $0.14 \%$, in TB cases without HIV coinfection.

The TB cure rate of $40.0 \%$ was lower than the rate verified by Oliveira et al. ${ }^{2}$ in Piaui State $(60.8 \%)$, by Silva et al..$^{32}$ in Alagoas State (57.03\%), and in Brazil between 2002-2012 (50.74\% $)^{31}$. The low cure rate must be analyzed with special attention by health authorities, as cure benefits not only the patient, but the entire social scope in which the patient is inserted, breaking the chain of transmission ${ }^{32}$, particularly in smear-positive pulmonary cases, the majority group in this study (60.6\%).

It was verified that the cure was associated with individuals between 40 and 49 years old, without diseases related to TB, probably because this group is composed by people who are more careful with their health since they do not use drugs, tobacco, and they do not drink alcoholic beverages in an abusive way and are possibly favored as they do not have diabetes, mental illness and other diseases concurrent to HIV/AIDS. A study carried out by Gaspar et $a l .{ }^{31}$ has shown that patients with TB/HIV have $48 \%$ less chance to be cured, $50 \%$ are more likely to stop the treatment and $94 \%$ are more likely to die from TB with respect to those without coinfection.

The deaths from other causes, excepting for TB, were associated with the ages between 30 and 39 years old, having AIDS and other diseases associated with TB registered as unknown, probably because the notification was made at the time of the death, explaining why the practitioner who made the notification failed to collect the information from the patient itself or from their family members. Deaths from TB totaled $7.2 \%$ of the notifications and deaths from other causes totaled $33.9 \%$. A study carried out in Amazonas State with cases of TB/HIV reported that deaths took place in the age group between 25 and 39 years old and were more likely to be notified, increasing the chance of TB notification by $40 \%{ }^{21}$. In Piaui State, the death rate was lower than the one in this study (3.5\%), and the same happened in a research carried out with national data (3.63\%) for patients with TB/ HIV $^{31}$ coinfection, and deaths from other causes have also shown a lower rate $(3.8 \%)^{2}$.

Prisoners totaled $3.9 \%$ of the cases. A study carried out in Alagoas State reported that people confined in overcrowded and unhealthy environments with inadequate ventilation had a higher exposure to risk factors related to the infection by Mycobacterium tuberculosis, but they found a lower proportion of cases $(2.84 \%)^{32}$.

On the other hand, homeless people in this study were $4.4 \%$, a fact that concerns the sanitary authorities, since they perpetuate the disease, particularly with respect to the optimization of treatment strategies in this target audience. Purely biomedical approaches have a limited effect on the cure, since they do not consider important factors predisposing to the disease ${ }^{33,34}$. Interventions should go beyond approaches to individual lifestyle factors, considering health inequalities that lead to exclusion, malnutrition, poor access to diagnostic services and health care, in addition to improper use of legal substances such as alcohol and tobacco, and illicit substances, like crack (cocaine). A study evaluated the experience of healthcare practitioners in the care of homeless people with TB, concluding that a complete human resource staff is not enough to provide health care for this population, as the adherence to treatment is complex. Factors such as intersectionality and availability of resources and government incentives are important, such as public transportation vouchers, basic food basket and the directly observed treatment $t^{35}$.

There was no registration of cases in healthcare practitioners. Despite being a risk group for this infection due to exposure to patients during the workday and shortage of administrative, environmental control, and individual protection measures ${ }^{36}$. Even in the absence of cases, it is necessary to be alert to the early diagnosis in this target audience, since the study carried out in the city of Vitoria, Espirito Santo State, with primary care health practitioners found a high prevalence of latent infection by Mycobacterium tuberculosis in this population, ranging from $39.4 \%$ to $54.1 \%$, with a higher proportion among the community health workers ${ }^{37}$.

As one of the main challenges of the Brazilian National Plan for the End of Tuberculosis as a Public Health Problem, it is important to improve the diagnostic network for TB and resistant TB; expand and maintain the RTR-TB; implement surveillance of TB deaths, latent infection and resistant TB; improve information systems for monitoring and decision-making purposes; strengthen the disease control actions in the most vulnerable populations; approach the 
disease in the perspective of social determinants; expand the decentralization and qualification of coping actions in basic care and improve the treatment outcome indicators ${ }^{24}$.

The limitations of the study include the use of secondary data sources with predetermined variables, with possible lack of information and underreporting of cases. However, since TB is a disease whose treatment is offered only in the public health network, the underreporting of this disease is likely to be reduced. A recent study in Amazonas State has indicated an underreporting rate of HIV cases of 7.7\%, while the national average was $6.9 \%{ }^{21}$.

People with communicable chronic diseases such as TB and HIV/AIDS are more likely to develop chronic noncommunicable diseases, and if they coexist with TB/HIV, they increase the risk or the effect of the other. Generally, resource-constrained healthcare services are unprepared to deal with the dual burden of the disease, and the care and specific approaches to the disease are not the most efficient response to treat the coinfection. Traditional approaches need to be reevaluated, with greater emphasis on the multidisciplinary approach with the assistance of integrated care management ${ }^{33,38-40}$.

\section{CONCLUSION}

The results indicate that abandonment of treatment should be reduced in vulnerable groups, late notification of TB only at death should be avoided, the proportion of treatment effectiveness should be increased, the molecular and sensitivity tests and adherence to the use of ART should be expanded. The inclusion of diseases associated with TB in the new notification form was correlated with treatment outcome, being an indicative of its relevance for the follow-up of new cases. Strategies for controlling the double burden of diseases (TB/HIV) should be reissued in the state in order to reach the goals of the Brazilian National Plan for the End of Tuberculosis as a Public Health Problem until 2035. There are points of weakness in the epidemiological surveillance in Minas Gerais State to comply with the protocol recommended for cases of TB with HIV coinfection.

\section{ACKNOWLEDGMENTS}

To the Postgraduate Program in Community Health of Ribeirao Preto Medical School, University of Sao Paulo, for the development of post-doctoral internship, and to the Secretary for Health of Minas Gerais State, Superintendence of Epidemiological, Environmental and Occupational Health Surveillance, for providing the database for this research.

\section{CONFLICT OF INTERESTS}

There are no conflict of interests.

\section{AUTHORS' CONTRIBUTIONS}

Sybelle de Souza Castro: conception, design, analysis and interpretation of data, article writing and critical review; Lúcia Marina Scatena: analysis and interpretation of data, article writing and critical review; Alfredo Miranzi: analysis and interpretation of data, article writing; Almir Miranzi Neto: analysis and interpretation of data, article writing; Altacílio Aparecido Nunes: conception and design, article writing and critical review. All authors approved the final version of the manuscript.

\section{REFERENCES}

1. World Health Organization. Global tuberculosis report 2017. [cited 2019 Feb 15]. Available from: http://www.who.int/tb/ publications/global_report/gtbr2017_main_text.pdf

2. Oliveira LB, Costar CR, Queiroz AA, Araújo TM, Sousa KA, Reis RK. Epidemiological analysis of tuberculosis/HIV coinfection. Cogitare Enferm. 2018;23:e51016.

3. Muniz JN, Ruffino-Netto A, Villa TC, Yamamura M, Arcencio R, Cardozo-Gonzales RI. Epidemiological aspects of human immunodeficiency virus/tuberculosis co-infection in Ribeirão Preto, Brazil from 1998 to 2003. J Bras Pneumol. 2006;32:529-34.

4. Machuca I, Vidal E, de la Torre-Cisneros J, Rivero-Román A. Tuberculosis in immunosuppressed patients. Enferm Infecc Microbiol Clin. 2017;36:366-74.

5. Guimarães RM, Lobo AP, Siqueira EA, Borges TF, Melo SC. Tuberculosis, HIV, and poverty: temporal trends in Brazil, the Americas, and worldwide. J Bras Pneumol. 2012;38:511-7.

6. Silva DR, Muñoz-Torrico M, Duarte R, Galvão T, Bonini EH, Arbex FF, et al. Risk factors for tuberculosis: diabetes, smoking, alcohol use, and the use of other drugs. J Bras Pneumol. 2018;44:145-52.

7. Fortes PD. A justa dose da medida: o tratamento compulsório da tuberculose em questão. Interface (Botucatu). 2016;20:743-51.

8. Silva HO, Gonçalves ML. Coinfecção tuberculose e HIV nas capitais brasileiras: observações a partir dos dados do Sistema de Informação de Agravos de Notificação. RBPS. 2009;22:172-8.

9. Feitoza DS, Clares JW, Rodrigues LV, Almeida PC. Vigilância epidemiológica no contexto do Programa de Controle da Tuberculose: limites e possibilidades. Rev Rene. 2012;13:106674.

10. Romero DE, Cunha CB. Avaliação da qualidade das variáveis epidemiológicas e demográficas do Sistema de Informação de Nascidos Vivos, 2002. Cad Saude Publica. 2007;23:701-14. 
11. Scatena LM, Villa TC, Netto AR, Kritski AL, Figueiredo TM, Vendramini SH, et al. Difficulties in the accessibility to health services for tuberculosis diagnosis in Brazilian municipalities. Rev Saude Publica. 2009;43:389-97.

12. Carvalho H. Análise multivariada de dados qualitativos: utilização da HOMALS com o SPSS. Lisboa: Sílabo; 2004.

13. Hair JF, Anderson RE, Black WC, Tatham RL, Babin BJ. Análise multivariada de dados. 6 ${ }^{\text {a }}$ ed. Porto Alegre: Bookman; 2009.

14. Bruchfeld J, Correia-Neves M, Källenius G. Tuberculosis and HIV coinfection. Cold Spring Harb Perspect Med. 2015;5:a017871.

15. Kumari P, Meena LS. Factors affecting susceptibility to Mycobacterium tuberculosis: a close view of immunological defence mechanism. Appl. Biochem Biotechnol. 2014; 174:2663-73.

16. Kwan CK, Ernst JD. HIV and tuberculosis: a deadly human syndemic. Clin Microbiol Rev. 2011;24:351-76.

17. Cruz VD, Harter J, Oliveira MM, Gonzales RI, Alves PF. Crack consumption and tuberculosis: an integrative review. SMAD Rev Eletr Saude Mental Alcool Drog. 2013;9:48.

18. Neves LA, Reis RK, Gir E. Compliance with the treatment by patients with the co-infection HIV/tuberculosis: integrative literature review. Rev Esc Enferm USP. 2010;44:1135-41.

19. Tiberi S, Carvalho AC, Sulis G, Vaghela D, Rendon A, Mello FC, et al. The cursed duet today: tuberculosis and HIV-coinfection. Presse Med. 2017;46:e23-39.

20. Viegas AM, Miranda SS, Haddad JP, Ceccato MG, Carvalho WS. Association of outcomes with comprehension, adherence and behavioral characteristics of tuberculosis patients using fixeddose combination therapy in Contagem, Minas Gerais, Brazil. Rev Inst Med Trop Sao Paulo. 2017;59:e28.

21. Magno ES, Saraceni V, Souza AB, Magno RS, Saraiva MG, Bührer-Sékula S. Fatores associados à coinfecção tuberculose e HIV: o que apontam os dados de notificação do Estado do Amazonas, Brasil, 2001-2012. Cad Saude Publica. 2017;33:e00019315

22. Alemie GA, Gebreselassie F. Common types of tuberculosis and co-infection with $\mathrm{HIV}$ at private health institutions in Ethiopia: a cross sectional study. BMC Public Health. 2014;14:319.

23. Andrade DF, Carvalho ML, Araújo TM, Sousa MA, Sá LC, Araújo EJ. Vantagens e usos do teste rápido molecular para tuberculose: uma revisão integrativa. Rev Enferm UFSM. 2017;7:123-35.

24. Brasil. Ministério da Saúde. Secretaria de Vigilância em Saúde. Departamento de Vigilância das Doenças Transmissíveis. Brasil livre da tuberculose: plano nacional pelo fim da tuberculose como problema de saúde pública. Brasília: Ministério da Saúde; 2017. [cited 2019 Feb 15]. Available from: http://bvsms.saude.gov.br/bvs/publicacoes/brasil_livre_ tuberculose_plano_nacional.pdf

25. Brasil. Ministério da Saúde. Secretaria de Vigilância em Saúde. Departamento de Vigilância das Doenças Transmissíveis.
Rede de teste rápido para tuberculose no Brasil: primeiro ano da implantação. Brasília: Ministério da Saúde; 2015. [cited 2019 Feb 15]. Available from: http://portalarquivos.saude. gov.br/images/pdf/2016/janeiro/19/rtr-tb-15jan16-isbn-web. pdf

26. Belo MT, Luiz RR, Hanson C, Selig L, Teixeira EG, Chalfoun T, et al. Tuberculosis and gender in a priority city in the state of Rio de Janeiro, Brazil. J Bras Pneumol. 2010;36:621-5.

27. Sotgiu G, Centis R, D'ambrosio L, Migliori GB. Tuberculosis treatment and drug regimens. Cold Spring Harb Perspect Med. 2015;5:a017822.

28. Lawn SD, Wood R, De Cock KM, Kranzer K, Lewis JJ, Churchyard GJ. Antiretrovirals and isoniazid preventive therapy in the prevention of HIV-associated tuberculosis in settings with limited health-care resources. Lancet Infect Dis. 2010;10:489-98.

29. Zachariah R, Bemelmans M, Akesson A, Gomani P, Phiri K, Isake $\mathrm{B}$, et al. Reduced tuberculosis case notification associated with scaling up antiretroviral treatment in rural Malawi. Int J Tuberc Lung Dis. 2011;15:933-7.

30. Churchyard G, Kim P, Shah NS, Rustomjee R, Gandhi N, Mathema $\mathrm{B}$, et al. What we know about tuberculosis transmission: an overview. J Infect Dis. 2017;216 Suppl 6:S629-35.

31. Gaspar RS, Nunes N, Nunes M, Rodrigues VP. Temporal analysis of reported cases of tuberculosis and of tuberculosis-HIV coinfection in Brazil between 2002 and 2012. J Bras Pneumol. 2016;42:416-22.

32. Silva EG, Vieira JD, Cavalcante AL, Santos LG, Rodrigues AP, Cavalcante TC. Perfil epidemiológico da tuberculose no Estado de Alagoas - AL de 2007 a 2012. Cad Grad Cien Biol Saúde. 2015;3:31-46.

33. Marais BJ, Lönnroth K, Lawn SD, Migliori GB, Mwaba P, Glaziou $\mathrm{P}$, et al. Tuberculosis comorbidity with communicable and non-communicable diseases: integrating health services and control efforts. Lancet Infect Dis. 2013;13:436-48.

34. Marmot MG, Allen J, Goldblatt P, Boyce T, McNeish D, Grady M, et al. Fair society, healthy lives: strategic review of health inequalities in England post-2010. London: The Marmot Review; 2010. [cited 2018 Feb 14]. Available from: https:// www.parliament.uk/documents/fair-society-healthy-lives-fullreport.pdf

35. Alecrim TF, Mitano F, Reis AA, Roos CM, Palha PF, ProttiZanatta ST. Experience of health professionals in care of the homeless population with tuberculosis. Rev Esc Enferm USP. 2016;50:808-15.

36. Joshi R, Reingold AL, Menzies D, Pai M. Tuberculosis among health-care workers in low- and middle-income countries: a systematic review. PLoS Med. 2006;3:e494.

37. Lacerda TC, Souza FM, Prado TN, Locatelli RL, Fregona G, Lima RC, et al. Tuberculosis infection among primary health care workers. J Bras Pneumol. 2017;43:416-23. 
38. Bygbjerg IC. Double burden of noncommunicable and infectious diseases in developing countries. Science. 2012;337:1499-501.

39. Lim SS, Vos T, Flaxman AD, Danaei G, Shibuya K, Adair-Rohani $\mathrm{H}$, et al. A comparative risk assessment of burden of disease and injury attributable to 67 risk factors and risk factor clusters in 21 regions, 1990-2010: a systematic analysis for the Global Burden of Disease Study 2010. Lancet. 2012;380:2224-60.
40. García-Fernández L, Benites C, Huamán B. Barreras para el acceso a la atención integral de las personas afectadas por la coinfección por tuberculosis y virus de inmunodeficiencia humana en Perú, 2010-2015. Rev Panam Salud Publica. 2017;41:e23. 